\title{
Association between Host Genetics of Sheep and the Rumen Microbial Composition
}

\author{
Sinalo Mani \\ University of KwaZulu Natal \\ Olayinka Ayobami Aiyegoro ( $\sim$ Aiyegoroo@arc.agric.za) \\ Agricultural Research Council https://orcid.org/0000-0001-6664-6574 \\ Matthew Adeniyi Adeleke \\ University of KwaZulu Natal
}

Research

Keywords: Host genetics, rumen microbiota, sheep, genome-wide association studies, candidate genes

Posted Date: November 20th, 2020

DOI: https://doi.org/10.21203/rs.3.rs-111081/v1

License: (c) (i) This work is licensed under a Creative Commons Attribution 4.0 International License. Read Full License

Version of Record: A version of this preprint was published at Tropical Animal Health and Production on February 22nd, 2022. See the published version at https://doi.org/10.1007/s11250-022-03057-2. 


\section{Abstract}

Background: The gut microbiome is very significant in the stability of the rumen ecosystem, also in the maintenance of the host's health. The gut flora influences the nutritional, physiological, immunological, and directly or indirectly affects the host's well-being. A synergy between the rumen microbiota and the host genetics creates a symbiotic relationship, beneficial to the host's health. In this study, the association between the host genetics and rumen microbiome of Damara and Meatmaster sheep was investigated. The composition of rumen microbiota was estimated through the analysis of the V3-V4 region of the 16S rRNA gene, while the sheep blood DNA was genotyped with Illumina OvineSNP50 BeadChip and the genome-wide association (GWA) was analyzed.

Results: Sixty significant SNPs dispersed in 21 regions across the Ovis aries genome were found to be associated with the relative abundance of seven genera: Acinetobacter, Bacillus, Clostridium, Flavobacterium, Prevotella, Pseudomonas and Streptobacillus. A total of eighty-four candidate genes were identified, and their functional annotations were mainly associated with immunity responses and function, metabolism, and signal transduction.

Conclusion: We are of the opinion, as evident from our results that candidate genes identified may be modulating the composition of rumen microbiota and, thus further indicate the significance of comprehending the interactions between the host and rumen microbiota to gain better insight into the health of sheep. We conclude that host genetics is important in modulating microbial composition; though various factors may alter the rumen microbiota. More studies are necessary to help determine genetic combinations favorable for the propagation of beneficial microbiota and provide excellent intestinal health.

\section{Introduction}

The gut microbiome is a complex network with a symbiotic relationship with the host; hence the microbiome composition may impact the balance of the rumen ecosystem, and their interaction provides beneficial functions to the host. The gut microbiome has a significant role in the maintenance of rumen ecosystem stability and the host's health, as it influences the nutritional, physiological, and immunological potential of the host $[1,2]$. The microbiota also extends the host's digestive capabilities, produce vitamins, and prevent pathogen colonization [3]. Likewise, the gut microbiota is essential in developing and differentiating the intestinal mucosal epithelium, and they modulate the host's immune response to maintain gut homeostasis.

The gut microbiome composition and function are modulated by factors such as age, diet, environment, and host genetics [4]. These factors influence how the microbiomes function and the microbial structure. Though it has been generally established that the significant factor modulating the gut microbial communities is diet [5, 6]; novel evidence through genome-wide association studies (GWAS), have shown that host genetics have a significant role in the modulation of gut microbial composition in mice and humans [7]. Blekhman et al. [8] showed an association between host genetic variation in SNPs and Bifidobacterium abundance close to the lactase (LCT) gene. LCT encodes for lactase enzyme that hydrolyzes lactose when expressed in the gastrointestinal tract. It has been suggested that host genetics is a vital component in modulating the gut microbial composition.

GWAS in animals has been mostly used to analyze several complex traits such as association with feed efficacy [9] and genetic resistance to diseases $[10,11]$. Despite its great significance, the compound relationship of host genetics, physiology, and gut microbiome components is poorly understood. Few studies assess the host genetics influence on the gut microbial composition [12]. Crespo- Piazuelo et al. [13] identified pig genetic variation SNPs that were associated with the abundance of six genera and the majority of candidate genes identified in 17 associated regions encoded for enzymes participating in defence systems of the host, while other proteins were involved in metabolism. Studies on the association of host genetics and their rumen microbiota composition are limited in ruminants, and those few are focused on cattle compared to other ruminants [7, 12]. In particular, association studies between rumen microbial composition and the sheep genome have not yet been defined. This study therefore aimed at identifying genomic regions in the host that may modulate the rumen microbial composition and find the correlation between host genetic variation and rumen microbial abundance through host-microbiota association in sheep.

\section{Materials And Methods}

\section{Animal material and sampling.}

All the procedures involving animals were permitted by the Agricultural Research Council - Animal Production Ethics committee (APIEC17/21). The trials were done at the Agricultural Research Council (ARC), GI Microbiology and Biotechnology unit, and the Small Stocks Unit in Irene, Gauteng province, South Africa. 
Sixty-four sheep (32 Damara sheep breed and 32 Meatmaster sheep breed) were used for the trial, and they were approximately seven months old with the average weight as follows: Meatmaster males $(24.6 \pm 3.4 \mathrm{~kg})$; Meatmaster females $(21.5 \pm 3.1 \mathrm{~kg})$; Damara males $(36.6 \pm 8.3 \mathrm{~kg})$; Damara females $(28.9 \pm 6.9 \mathrm{~kg})$. The animals were housed per treatment with males and females separated in open barn trial pens with $\pm 4 \mathrm{~m}^{2}$ shelters. Ten (10) animals were excluded from the experiment after adaptation period before the trial commenced, due to signs of sickness and 4 mortalities. The animals were grouped into five treatment groups and were fed on commercial pellet feed, with hay and fresh water supplied ad libitum. Rumen and blood samples were collected before the trial commenced and later collected again at the end of the trial. Rumen samples were collected using a stomach tube following the procedures of Shen et al. [14].

\section{Microbial DNA extraction, 16S rRNA gene amplification and sequencing}

Microbial DNA was extracted with QIAamp Fast DNA stool Mini Kit (Qiagen, Germany) following the guidelines of the manufacturer for pathogen detection, and DNA concentration was evaluated with Nanodrop 2000 (Thermo Electron Corporation, USA). The DNA samples were pooled according to their respective treatments, taking into consideration the sex of the animals (males and females DNA pooled separately). The pooled DNA quality was evaluated using gel electrophoresis on $1.5 \%$ agarose gels and visualized with UVP BioSpectrum 310 Imaging System (FisherScientific, UK). The pooled DNA samples were used as templates for amplifying the V3-V4 hypervariable region of the prokaryotic 16S rRNA gene according to the 16S Metagenomic Sequencing Library Preparation guide (Illumina, San Diego, USA). Illumina MiSeq platform was used to perform sequencing, and 300 bp paired-end reads were generated. Raw reads were deposited to the Sequence Read Archive (SRA) of the National Center of Biotechnology Information (NCBI) database under BioProject PRJNA578022.

\section{Data analysis}

Raw data sequences generated by MiSeq Illumina were trimmed employing Trimmomatics (version 0.36), Illumina universal adapter sequences, and the low-quality sequence regions were removed. Demultiplexed sequence files were imported to QIIME2 software (version 2018.8) [15] for analysis. The imported reads were denoised and trimmed using DADA2. Sequences were assigned to operational taxonomic units (OTU) with $97 \%$ identity, and the OTU feature table was generated; chimeric sequences were detected and removed from the representative OTU sequences. For taxonomic analysis, OTU representative sequences were aligned to the Greengenes database. All other statistical analyses were carried out using phyloseq package (version 1.24.2) through RStudio (version 3.5.3). The 9134 OTUs were grouped into 20 phyla and 107 genera through tax_glom method in the phyloseq method in R. OTUs with the relative abundance of $\geq$ $0.05 \%$ in at least one sample were the ones retained in both breeds for subsequent analyses.

\section{Host DNA extraction and SNP genotyping}

Sheep whole blood was used to extract DNA with Wizard ${ }^{\mathrm{TM}}$ Genomic DNA Purification Kit (Promega, USA). DNA samples for each breed were pooled according to their respective treatments, taking into consideration the sex of the animals (males and females DNA pooled separately). DNA quality and quantity were measured using 1.5\% agarose gel electrophoresis (Bio-Rad) and Qubit 2.0 Fluorometer (Life Technologies), respectively. Genotyping of 40 DNA samples was done with the Illumina OvineSNP50 BeadChip (Illumina, San Diego, CA). Genotypes were obtained using GenomeStudio software and quality control of the data was done through PLINK software (version 1.9) [16]. Additional analyses were performed only on SNPs that mapped and aligned to the Oar_v3.1 reference assembly, retaining a total of 42503 SNPs with missing genotype $<2 \%$ and minor allele frequency (MAF) $>2 \%$ to be used for genome-wide association analysis.

\section{Genome-wide association (GWA) analysis}

Associations between the SNPs mapped to the genome and microbiota composition at the genus level were carried out. Samples were normalized by their relative abundance and find.top.taxa function in R was used to extract genera that were present in $\geq 90 \%$ of the samples in both sheep breeds and had more than $0.05 \%$ of the total reads to avoid errors caused by low abundant genera. Unspecified genera were excluded from the analysis; thus, GWAS was carried out in 7 out of the 107 found genera. GWAS analysis was performed using PLINK and multiple test correction with false discovery rate (FDR) method [17] using -adjust function in plink.

\section{Functional gene annotation and prediction}


Associated regions in the sheep genome were annotated at $1 \mathrm{Mb}$ on each side of Oar_3.1. Gene locations were based on the Ensembl Genome Browser (www.ensembl.org; release 99). The genes contained in the regions of significant SNPs in the sheep genome were extracted using Oar_3.1 reference in the Biomart tool [18] using Ensembl. Variant Effect Predictor tool [19] from the Ensembl project was used in predicting the functional consequences of the significant SNPs.

\section{Results}

GWAS was achieved using 42,503 SNPs in 40 animal genotypes and the relative abundance of seven genera; Acinetobacter, Bacillus, Clostridium, Flavobacterium, Prevotella, Pseudomonas and Streptobacillus. Significant associations (FDR $<0.1)$ were found in all seven genera and 60 significant SNPs were dispersed in 21 chromosomes across the Ovis aries genome (Fig. 1 and Table 1). There were two shared regions found for the abundance of Prevotella and Bacillus, located in the region of 25.47 26.10 Mbps on OAR17, Bacillus and Acinetobacter shared a region of $45.13 \sim 49.52 \mathrm{Mbps}$ located on OAR26; also they were associated with one SNP (s22112.1 on OAR26, $P$ $=1.29 \mathrm{e}-20-3.95 \mathrm{e}-08, \mathrm{FDR}=2.24 \mathrm{e}-17-8.45 \mathrm{e}-05)$. Bacillus and Clostridium are members of Firmicutes phylum, Prevotella and

Flavobacterium from the Bacteroidetes phylum, Streptobacillus belonging to Fusobacteria. Pseudomonas and Acinetobacter are genera of Proteobacteria phylum. Eighty-four candidate genes were identified in the regions of significant SNPs associated with rumen microbial composition. 
Table 1

Significant variant regions associated with the relative abundance of microbial genera and identified candidate genes within the regions

\begin{tabular}{|c|c|c|c|c|c|c|c|}
\hline SNP & Chr & Position & $\begin{array}{l}\mathrm{p}- \\
\text { value }\end{array}$ & FDR & Genus & Consequence & $\begin{array}{l}\text { Candidate } \\
\text { genes }\end{array}$ \\
\hline OAR1_41851018.1 & 1 & $40,438,064$ & $\begin{array}{l}2.09 \mathrm{E}- \\
09\end{array}$ & 1.73E-05 & Acinetobacter & downstream_gene_variant & $A K 4, L E P R$ \\
\hline OAR3_20690836.1 & 3 & $19,172,977$ & $\begin{array}{l}6.72 \mathrm{E}- \\
09\end{array}$ & 3.57E-05 & Acinetobacter & upstream_gene_variant & $\begin{array}{l}\text { ITGB1BP1, } \\
\text { ROCK2 }\end{array}$ \\
\hline OAR10_46135260.1 & 10 & $45,590,208$ & $\begin{array}{l}6.90 \mathrm{E}- \\
09\end{array}$ & 3.57E-05 & Acinetobacter & upstream_gene_variant & \\
\hline s50123.1 & 22 & $42,997,377$ & $\begin{array}{l}9.24 \mathrm{E}- \\
11\end{array}$ & $1.28 \mathrm{E}-06$ & Acinetobacter & downstream_gene_variant & $\begin{array}{l}\text { CHST15, } \\
\text { ABRAXAS2, } \\
\text { ZRANB1 }\end{array}$ \\
\hline s04636.1 & 25 & $43,727,893$ & $\begin{array}{l}2.09 \mathrm{E}- \\
09\end{array}$ & 1.73E-05 & Acinetobacter & downstream_gene_variant & $\begin{array}{l}\text { WDFY4, } \\
\text { OGDHL, } \\
\text { DEPP1 }\end{array}$ \\
\hline OAR26_46995252.1 & 26 & $41,441,325$ & $\begin{array}{l}8.65 \mathrm{E}- \\
11\end{array}$ & $1.28 \mathrm{E}-06$ & Acinetobacter & downstream_gene_variant & NR1D2 \\
\hline s22112.1 & 26 & $42,948,826$ & $\begin{array}{l}3.95 \mathrm{E}- \\
08\end{array}$ & $8.45 \mathrm{E}-05$ & Acinetobacter & downstream_gene_variant & \\
\hline s50736.1 & 26 & $43,029,260$ & $\begin{array}{l}5.26 \mathrm{E}- \\
09\end{array}$ & 3.57E-05 & Acinetobacter & downstream_gene_variant & \\
\hline OAR26_49520304.1 & 26 & $43,626,043$ & $\begin{array}{l}3.46 \mathrm{E}- \\
20\end{array}$ & $1.43 \mathrm{E}-15$ & Acinetobacter & downstream_gene_variant & \\
\hline OAR1_142723820.1 & 1 & $131,856,629$ & $\begin{array}{l}9.92 \mathrm{E}- \\
27\end{array}$ & 4.12E-23 & Bacillus & downstream_gene_variant & \\
\hline OAR1_221226809.1 & 1 & $204,866,048$ & $\begin{array}{l}9.92 \mathrm{E}- \\
27\end{array}$ & 4.12E-23 & Bacillus & downstream_gene_variant & \\
\hline OAR2_107495304.1 & 2 & $99,900,131$ & $\begin{array}{l}8.51 \mathrm{E}- \\
24\end{array}$ & 2.19E-20 & Bacillus & downstream_gene_variant & SCARA3 \\
\hline s04253.1 & 2 & $126,963,279$ & $\begin{array}{l}4.00 \mathrm{E}- \\
20\end{array}$ & $6.39 \mathrm{E}-17$ & Bacillus & downstream_gene_variant & ITGA4 \\
\hline OAR2_135296252.1 & 2 & $127,014,456$ & $\begin{array}{l}7.29 \mathrm{E}- \\
18\end{array}$ & $1.01 \mathrm{E}-14$ & Bacillus & downstream_gene_variant & ITGA4 \\
\hline OAR2_153029366.1 & 2 & $144,088,879$ & $\begin{array}{l}7.30 \mathrm{E}- \\
18\end{array}$ & $1.01 \mathrm{E}-14$ & Bacillus & upstream_gene_variant & GRB14 \\
\hline OAR3_135035896.1 & 3 & $126,551,306$ & $\begin{array}{l}8.30 \mathrm{E}- \\
21\end{array}$ & $1.50 \mathrm{E}-17$ & Bacillus & upstream_gene_variant & $A T P 2 B 1$ \\
\hline s27957.1 & 4 & $71,282,342$ & $\begin{array}{l}9.49 \mathrm{E}- \\
24\end{array}$ & $2.19 \mathrm{E}-20$ & Bacillus & downstream_gene_variant & $\begin{array}{l}\text { OSBPL3, NPY, } \\
\text { ADAM22 }\end{array}$ \\
\hline OAR4_93149584.1 & 4 & $87,732,399$ & $\begin{array}{l}3.39 \mathrm{E}- \\
28\end{array}$ & 4.69E-24 & Bacillus & upstream_gene_variant & \\
\hline OAR6_16061983.1 & 6 & $13,457,100$ & $\begin{array}{l}8.07 \mathrm{E}- \\
21\end{array}$ & $1.50 \mathrm{E}-17$ & Bacillus & downstream_gene_variant & $A L P K 1, T I F A$ \\
\hline OAR6_120140225.1 & 6 & $105,688,605$ & $\begin{array}{l}9.92 \mathrm{E}- \\
27\end{array}$ & 4.12E-23 & Bacillus & upstream_gene_variant & \\
\hline OAR7_862379.1 & 7 & $1,175,686$ & $\begin{array}{l}3.24 \mathrm{E}- \\
21\end{array}$ & $6.72 \mathrm{E}-18$ & Bacillus & downstream_gene_variant & $\begin{array}{l}M C C \\
E P B 41 \angle 4 A\end{array}$ \\
\hline OAR10_52665226.1 & 10 & $51,659,456$ & $\begin{array}{l}9.92 \mathrm{E}- \\
27\end{array}$ & $4.12 \mathrm{E}-23$ & Bacillus & upstream_gene_variant & $A C O D 1$ \\
\hline
\end{tabular}

Chr: Chromosome. FDR $\leq 0.1$. 


\begin{tabular}{|c|c|c|c|c|c|c|c|}
\hline SNP & Chr & Position & $\begin{array}{l}\text { p- } \\
\text { value }\end{array}$ & FDR & Genus & Consequence & $\begin{array}{l}\text { Candidate } \\
\text { genes }\end{array}$ \\
\hline OAR10_64413399.1 & 10 & $62,506,487$ & $\begin{array}{l}8.51 \mathrm{E}- \\
24\end{array}$ & 2.19E-20 & Bacillus & upstream_gene_variant & \\
\hline OAR11_18077431.1 & 11 & $17,728,327$ & $\begin{array}{l}2.90 \mathrm{E}- \\
25\end{array}$ & 1.00E-21 & Bacillus & upstream_gene_variant & TMEM98 \\
\hline s39842.1 & 11 & $54,939,690$ & $\begin{array}{l}3.39 \mathrm{E}- \\
28\end{array}$ & 4.69E-24 & Bacillus & upstream_gene_variant & $\begin{array}{l}\text { MGAT5B, } \\
\text { ST6GALNAC2, } \\
\text { CYGB, SPHK1, } \\
\text { GALR2, } \\
\text { GALK1, } \\
\text { SLC16A5, } \\
\text { OTOP3, } \\
\text { OTOP2 }\end{array}$ \\
\hline OAR12_72007015.1 & 12 & $65,405,613$ & $\begin{array}{l}7.99 \mathrm{E}- \\
27\end{array}$ & $4.12 \mathrm{E}-23$ & Bacillus & upstream_gene_variant & PLA2G4A \\
\hline OAR13_28884642.1 & 13 & $26,065,987$ & $\begin{array}{l}3.56 \mathrm{E}- \\
21\end{array}$ & $7.04 \mathrm{E}-18$ & Bacillus & downstream_gene_variant & GAD2, OPTN \\
\hline OAR15_69064778.1 & 15 & $63,508,604$ & $\begin{array}{l}8.51 \mathrm{E}- \\
24\end{array}$ & 2.19E-20 & Bacillus & downstream_gene_variant & $C D 44$ \\
\hline OAR16_32396433.1 & 16 & $29,834,628$ & $\begin{array}{l}2.15 \mathrm{E}- \\
19\end{array}$ & 3.30E-16 & Bacillus & downstream_gene_variant & FGF10 \\
\hline s00547.1 & 17 & $7,870,359$ & $\begin{array}{l}1.04 \mathrm{E}- \\
25\end{array}$ & $3.94 \mathrm{E}-22$ & Bacillus & downstream_gene_variant & \\
\hline OAR17_25477049.1 & 17 & $23,080,103$ & $\begin{array}{l}9.32 \mathrm{E}- \\
24\end{array}$ & $2.19 \mathrm{E}-20$ & Bacillus & upstream_gene_variant & \\
\hline OAR19_26906414.1 & 19 & $25,469,429$ & $\begin{array}{l}3.17 \mathrm{E}- \\
25\end{array}$ & $1.00 \mathrm{E}-21$ & Bacillus & upstream_gene_variant & CNTN6, CHL 1 \\
\hline OAR20_24435276.1 & 20 & $23,004,273$ & $\begin{array}{l}2.17 \mathrm{E}- \\
16\end{array}$ & $2.90 \mathrm{E}-13$ & Bacillus & downstream_gene_variant & $\begin{array}{l}\text { MMUT, } \\
\text { GLYATL3, } \\
\text { DEFB133, } \\
D E F B 113, \\
D E F B 110\end{array}$ \\
\hline s04766.1 & 20 & $40,540,580$ & $\begin{array}{l}7.16 \mathrm{E}- \\
15\end{array}$ & $9.29 \mathrm{E}-12$ & Bacillus & downstream_gene_variant & \\
\hline OAR21_23489027.1 & 21 & $20,825,320$ & $\begin{array}{l}9.92 \mathrm{E}- \\
27\end{array}$ & $4.12 \mathrm{E}-23$ & Bacillus & upstream_gene_variant & \\
\hline OAR23_39546165.1 & 23 & $37,298,993$ & $\begin{array}{l}3.39 \mathrm{E}- \\
28\end{array}$ & 4.69E-24 & Bacillus & upstream_gene_variant & LPIN2 \\
\hline DU481531_204.1 & 26 & $5,940,221$ & $\begin{array}{l}2.74 \mathrm{E}- \\
09\end{array}$ & $3.45 \mathrm{E}-06$ & Bacillus & downstream_gene_variant & AGPAT5 \\
\hline OAR26_45130684.1 & 26 & $39,909,046$ & $\begin{array}{l}1.10 \mathrm{E}- \\
22\end{array}$ & 2.39E-19 & Bacillus & upstream_gene_variant & NR1D2 \\
\hline OAR26_46516694.1 & 26 & $41,052,798$ & $\begin{array}{l}3.99 \mathrm{E}- \\
20\end{array}$ & $6.39 \mathrm{E}-17$ & Bacillus & downstream_gene_variant & NR1D2 \\
\hline OAR26_48188219.1 & 26 & $42,498,856$ & $\begin{array}{l}5.80 \mathrm{E}- \\
18\end{array}$ & 8.59E-15 & Bacillus & downstream_gene_variant & \\
\hline s46142.1 & 26 & $42,685,548$ & $\begin{array}{l}9.92 \mathrm{E}- \\
27\end{array}$ & $4.12 \mathrm{E}-23$ & Bacillus & downstream_gene_variant & \\
\hline s22112.1 & 26 & $42,948,826$ & $\begin{array}{l}1.29 \mathrm{E}- \\
20\end{array}$ & $2.24 \mathrm{E}-17$ & Bacillus & downstream_gene_variant & \\
\hline s43106.1 & 2 & $16,687,851$ & $\begin{array}{l}1.02 \mathrm{E}- \\
10\end{array}$ & $2.11 \mathrm{E}-06$ & Clostridium & downstream_gene_variant & $\begin{array}{l}R A D 23 B \\
S L C 44 A 1\end{array}$ \\
\hline
\end{tabular}

Chr: Chromosome. FDR $\leq 0.1$. 


\begin{tabular}{|c|c|c|c|c|c|c|c|}
\hline SNP & Chr & Position & $\begin{array}{l}\mathrm{p}- \\
\text { value }\end{array}$ & FDR & Genus & Consequence & $\begin{array}{l}\text { Candidate } \\
\text { genes }\end{array}$ \\
\hline OAR2_58286833_X.1 & 2 & $54,173,591$ & $\begin{array}{l}6.24 \mathrm{E}- \\
12\end{array}$ & $2.59 \mathrm{E}-07$ & Clostridium & downstream_gene_variant & TLE1 \\
\hline OAR1_74421103.1 & 1 & $69,799,470$ & $\begin{array}{l}1.14 \mathrm{E}- \\
06\end{array}$ & 0.005818 & Flavobacterium & upstream_gene_variant & $\begin{array}{l}\text { GFI1, FNBP1L, } \\
A B C D 3\end{array}$ \\
\hline OAR1_197593478.1 & 1 & $183,138,836$ & $\begin{array}{l}1.14 \mathrm{E}- \\
06\end{array}$ & 0.005818 & Flavobacterium & upstream_gene_variant & $\begin{array}{l}\text { IGSF11, } \\
\text { B4GALT4, } \\
\text { ARHGAP31 }\end{array}$ \\
\hline OAR2_247207503.1 & 2 & $234,119,904$ & $\begin{array}{l}7.94 \mathrm{E}- \\
07\end{array}$ & 0.005818 & Flavobacterium & downstream_gene_variant & $A K 2, L C K$ \\
\hline OAR6_58751558.1 & 6 & $53,388,884$ & $\begin{array}{l}2.34 \mathrm{E}- \\
06\end{array}$ & 0.01024 & Flavobacterium & upstream_gene_variant & \\
\hline OAR16_37770793_X.1 & 16 & $34,690,414$ & $\begin{array}{l}1.14 \mathrm{E}- \\
06\end{array}$ & 0.005818 & Flavobacterium & upstream_gene_variant & $\begin{array}{l}\text { C9, PTGER4, } \\
\text { RICTOR, } \\
\text { FYB1, DAB2 }\end{array}$ \\
\hline OAR22_26777966.1 & 22 & $22,682,679$ & $\begin{array}{l}1.14 \mathrm{E}- \\
06\end{array}$ & 0.005818 & Flavobacterium & downstream_gene_variant & $\begin{array}{l}\text { NFKB2, } \\
\text { TRIM8, } \\
\text { CNNM2, } \\
\text { FGF8, ELOVL3 }\end{array}$ \\
\hline OAR23_54064411.1 & 23 & $51,039,178$ & $\begin{array}{l}7.94 \mathrm{E}- \\
07\end{array}$ & 0.005818 & Flavobacterium & upstream_gene_variant & SMAD4 \\
\hline OAR1_286871592.1 & 1 & $265,164,196$ & $\begin{array}{l}6.85 \mathrm{E}- \\
06\end{array}$ & 0.04737 & Prevotella & downstream_gene_variant & $R U N X 1$ \\
\hline OAR4_36089897.1 & 4 & $34,178,907$ & $\begin{array}{l}3.94 \mathrm{E}- \\
06\end{array}$ & 0.04737 & Prevotella & upstream_gene_variant & GRM3 \\
\hline OAR7_56932867.1 & 7 & $51,557,993$ & $\begin{array}{l}6.09 \mathrm{E}- \\
06\end{array}$ & 0.04737 & Prevotella & downstream_gene_variant & $\begin{array}{l}\text { NEDD4, } \\
\text { RAB27A }\end{array}$ \\
\hline s21876.1 & 16 & $5,145,810$ & $\begin{array}{l}3.65 \mathrm{E}- \\
06\end{array}$ & 0.04737 & Prevotella & upstream_gene_variant & $\begin{array}{l}\text { DUSP1, } \\
\text { BNIP1, STC2 }\end{array}$ \\
\hline OAR17_26108276.1 & 17 & $23,624,423$ & $\begin{array}{l}5.21 \mathrm{E}- \\
06\end{array}$ & 0.04737 & Prevotella & upstream_gene_variant & \\
\hline s20119.1 & 25 & $42,915,079$ & $\begin{array}{l}5.88 \mathrm{E}- \\
06\end{array}$ & 0.04737 & Prevotella & upstream_gene_variant & $\begin{array}{l}\text { MAPK8, } \\
\text { WDFY4, } \\
\text { OGDHL }\end{array}$ \\
\hline OAR6_24191777.1 & 6 & $21,117,639$ & $\begin{array}{l}2.41 \mathrm{E}- \\
07\end{array}$ & 0.009996 & Pseudomonas & downstream_gene_variant & $\begin{array}{l}\text { BDH2, } \\
\text { SLC9B2, } \\
\text { CISD2 }\end{array}$ \\
\hline OAR14_27438486.1 & 14 & $26,265,288$ & $\begin{array}{l}5.95 \mathrm{E}- \\
07\end{array}$ & 0.01234 & Pseudomonas & upstream_gene_variant & $\begin{array}{l}\text { CSNK2A2, } \\
\text { GOT2 }\end{array}$ \\
\hline s75574.1 & 25 & $35,576,136$ & $\begin{array}{l}1.97 \mathrm{E}- \\
34\end{array}$ & 7.11E-30 & Streptobacillus & downstream_gene_variant & $\begin{array}{l}\text { SFTPA1, } \\
P R X L 2 A\end{array}$ \\
\hline
\end{tabular}

\section{Discussion}

Previous studies have demonstrated that host genetics play a role in modulating the composition of gut microbiota in mammals $[3,7,8$, 13]. The results in this study suggest that there are associations between the abundance of certain genera and host genotypes (SNPs), which might provide answers on which genetic components contribute to the rumen microbial composition. Some of the microorganisms that showed to be related to host genetics are relevant in the composition of the ruminal environment, degradation of feed. The detailed description of the candidate genes mapped in the sheep genome's significant genetic variations is discussed.

\section{Acinetobacter}


The relative abundance of Acinetobacter is associated with genetic variations in six sheep genome regions. In the region OAR1, two candidate genes have been identified; Adenylate Kinase 4 (AK4) and Leptin Receptor (LEPR). AK4 regulates the activation of the energy sensor and phosphorylation AMPK protein kinase by controlling cellular ATP levels. The kinase is also essential in oxidative stress cellular defence response $[20,21]$. While $L E P R$ is a receptor for leptin, which is a hormone that is adipocyte-specific regulating body weight [22]. In the region of OAR3, two candidate genes were found; Integrin Subunit Beta 1 Binding Protein 1 (ITGB1BP1) and Rho Associated CoiledCoil Containing Protein Kinase 2 (ROCK2). ITGB1BP1 is essential for cell adhesion, proliferation, differentiation and migration [23]. ROCK2 is vital for regulating cell polarity and the actin cytoskeleton. $R O C K 2$ is also involved in regulating the smooth muscle contraction, neurite retraction, cell adhesion and motility, stress fibre, actin cytoskeleton organization and focal adhesion formation [24]. ROCK2 might be involved in regulating the rumen smooth muscle contraction. A study by Xiang et al. [25] reported that increased expression of genes regulating smooth muscle contraction in the rumen is related to sheep with shorter mean retention time (MRT), as the muscle contraction reduces MRT and subsequently the $\mathrm{CH}_{4}$. This may increase gastrointestinal muscle contraction linked to the rapid digesta passage rate, thus influencing rumen microbiota.

Three candidate genes found in the region of OAR22, Carbohydrate Sulfotransferase 15 (CHST15), Abraxas 2, BRISC Complex Subunit (ABRAXAS2) and Zinc Finger RANBP2-Type Containing 1 (ZRANB1). CHST15 is essential in glycosaminoglycan metabolism, a significant structural constituent of the extracellular matrix and this gene potentially acts as a B-cell surface signaling receptor [26]. ABRAXAS2 is involved in the deubiquitination of the interferon receptor IFNAR1 involved in interferon signaling, and it also down-regulates bacterial lipopolysaccharide (LPS) response [27]. ZRANB1 is essential in cell migration and stress fibre dynamics; it might also modulate TNFalpha signaling [28]. In the region of OAR25, three candidate genes were found, WDFY family member 4 (WDFY4), oxoglutarate dehydrogenase-like (OGDHL) and DEPP1 autophagy regulator (DEPP1). WDFY4 plays a significant role in regulating CDC1-mediated crosspresentation of viral and tumor antigens in dendritic cells. It is also known to be essential in B-cell survival through autophagy regulation [29]. OGDHL encodes for protein similar that degrades glucose and glutamate [30]. DEPP1 is known as fasting-induced gene as its expression is induced by fasting and progesterone and is a vital modulator of FOXO3-induced autophagy via oxidative stress [31]. While no candidate gene was found in other genetic variations in the region of OAR26, the genetic variant with significant SNP OAR26_46995252.1 contained nuclear receptor subfamily 1 group D member 2 (NR1D2) identified. NR1D2 regulates genes essential in metabolic functions such as lipid metabolism and the inflammatory response [32]. Acinetobacter is said to be more involved in epithelial proliferation and disease [33] and these genes might modulate the abundance of Acinetobacter.

\section{Bacillus}

In the gut, Bacillus is known to partake in the metabolism of nutrients and is involved in the maintenance of intestinal homeostasis [34]. The relative abundance of Bacillus is associated with genetic variations in 18 regions of the sheep genome; no candidate gene was found in three of the regions. In OAR2, significant SNP OAR2_107495304.1 was located in the region of scavenger receptor class A member 3 (SCARA3). SCARA3 has been shown to deplete reactive oxygen species as it's known as a cellular stress response gene and thus has a significant function in the protection of cells from oxidative stress [35]. Two significant SNP s04253.1 and OAR2_135296252.1 were located in the region of integrin subunit alpha 4 (ITGA4). ITGA4 encodes a protein in the integrin alpha chain family; integrins are a key class of cell surface receptors mediating associations of cells and extracellular matrix and are essential in cell surface adhesion and signaling [36]. Significant SNP OAR2_153029366.1 contained growth factor receptor-bound protein 14 (GRB14) that may be modulating Bacillus abundance as it plays a role in inhibiting the signaling of the insulin receptor, inducing insulin resistance [37]. The region of OAR3 contained ATPase Plasma Membrane Ca2 + Transporting 1 (ATP2B1), which catalyzes the ATP hydrolysis attached to calcium transport from the cytoplasm to the extracellular space thereby playing a vital role in intracellular calcium homeostasis [38].

Three candidate genes found in the region of OAR4; Oxysterol Binding Protein like 3 (OSBPL3), Neuropeptide Y (NPY) and ADAM Metallopeptidase Domain 22 (ADAM22). OSBPL3 is essential in regulating actin cytoskeleton, cell adhesion, cell polarity and cellular lipid metabolism [39]. NPY acts as a neuromodulator and is involved in several physiological processes, including stress response, food intake, cardiovascular function and circadian rhythms [40]. ADAM22 is involved in the regulating cell adhesion and inhibiting cell proliferation [41]. In the region of OAR6, two candidate genes were identified; alpha kinase 1 (ALPK1) and TRAF Interacting Protein with Forkhead Associated Domain (TIFA). ALPK1 initiates an innate immune response triggered by the detection of bacterial pathogen-associated molecular pattern metabolites (PAMPs), which is vital for eliminating pathogens and engaging adaptive immunity [42]. TIFA encodes an adapter protein essential in adaptive and innate immunity by activating proinflammatory NF-kappa-B signaling following the detection of bacterial PAMPs [43]. In the region of OAR7, two candidate genes were found MCC regulator of WNT signaling pathway $(M C C)$ and erythrocyte membrane protein band 4.1 like $4 A(E P B 41 L 4 A)$. MCC plays a part in cell migration [44]. While EPB41L4A product NBL4 is said to play a role in the beta-catenin signaling pathway. Beta-catenin regulates and coordinates cell-cell adhesion and gene transcription

Page $8 / 19$ 
[45]. Region of OAR10 contained aconitate decarboxylase 1 (ACOD1) that is essential in the antimicrobial response of innate immune cells by producing itaconic acid that is involved in the antimicrobial activity of macrophages [46]. Transmembrane Protein 98 (TMEM98) is found in one region of OAR11 and the secreted form of this gene promotes T helper 1 cells (Th1) differentiation [47].

Nine candidate genes were identified in the second region of OAR11; Alpha-1,6-Mannosylglycoprotein 6-Beta-NAcetylglucosaminyltransferase B (MGAT5B), Acetylgalactosaminide Alpha-2,6-Sialyltransferase 2 (ST6GALNAC2), Cytoglobin (CYGB), Sphingosine Kinase 1 (SPHK1), Galanin Receptor 2 (GALR2), Galactokinase 1 (GALK1), Solute Carrier Family 16 Member 5 (SLC16A5), Otopetrin 2 (OTOP2) and Otopetrin 3 (OTOP3). MGAT5B is essential in the 0-mannosyl glycan pathway, and the modulation of integrin and laminin-dependent adhesion and neuronal cell migration [48]. ST6GALNAC2 has roles at the cell surfaces in bacterial adhesion, protein targeting and cell-cell and cell-substrate interactions [49]. CYGB might have a protective function against oxidative stress conditions and might have a role in intracellular oxygen storage or transfer [50]. SPHK1 and its product S1P are essential in the NF-kappaB activation pathway and TNF-alpha signaling essential in immune processes [51]. GALR2 expresses galanin, an important neuromodulator present in the gastrointestinal system, brain and hypothalamopituitary axis. Also essential in regulating the growth hormone release and modulation of insulin release [52]. GALK1 is a major enzyme for galactose metabolism [53]. SLC16A5 catalyzes the prompt transport of many monocarboxylates such as branched-chain oxo acids derived from leucine, pyruvate, lactate ketone bodies acetoacetate, valine and isoleucine, beta-hydroxybutyrate and acetate across the plasma membrane [54]. OTOP2 and OTOP3 are protonselective channels that transport protons specifically into cells. The activity of these channels is possibly essential in cell types that use intracellular pH changes for cell signaling or the regulation of biochemical or developmental processes [55].

In the region of OAR12, Phospholipase A2 Group IVA (PLA2G4A) was proposed as a candidate gene as these are a group of enzymes hydrolyzing phospholipids into fatty acids and other lipophilic molecules [56]. Two candidate genes found in the region of OAR13; Glutamate Decarboxylase 2 (GAD2) and Optineurin (OPTM). GAD2 encodes one of the various forms of glutamic acid decarboxylase and has been recognized as a vital autoantigen in insulin-dependent diabetes [56]. OPTN is involved in innate immune response activation during viral infections [57]. CD44 Molecule (Indian Blood Group) was found in the region of OAR15 and this gene encodes for a cellsurface glycoprotein essential in cell adhesion, cell-cell interactions and migration. This glycoprotein also participates in other cellular functions such as activation and homing T-lymphocytes, inflammation and response to bacterial infections [58, 59]. The region of OAR16 contained Fibroblast Growth Factor 10 (FGF10) that is essential in regulating the development of an embryo, cell proliferation and differentiation. FGF10 may be involved in wound healing [60]. Two candidate genes found in the region of OAR19; Contactin 6 (CNTN6) and cell adhesion molecule L1 like (CHL1). CNTN6 and CHL 1 encode for proteins that function as cell adhesion molecules, these molecules are known to interact and have a key role in inflammatory responses [61, 62].

In the region of OAR20, five candidate genes were identified; Methylmalonyl-CoA Mutase (MMUT), Glycine-N-Acyltransferase Like 3 (GLYATL3), Defensin Beta 133 (DEFB133), Defensin Beta 113 (DEFB113) and Defensin Beta 110 (DEFB110). MMUT plays a role in degrading various amino acids, cholesterol and odd-chain fatty acids via propionyl-CoA to the tricarboxylic acid cycle [63]. GLYATL3 catalyzes the conjugation of long-chain fatty acyl-CoA thioester and glycine producing long-chain $\mathrm{N}$-(fatty acyl) glycine intermediate in the primary fatty acid amide biosynthetic pathway [64]. DEFB133, DEFB113 and DEFB110 are a family of antimicrobial and cytotoxic peptides that are made by neutrophils. They have innate immune defence response to bacteria [64]. Lipin 2 (LPIN2) is found in the region of OAR23 and plays a significant role in regulating fatty acids metabolism at different levels [65]. Two candidate genes found in the region of OAR26 associated with three significant SNPs; 1-Acylglycerol-3-phosphate 0-acyltransferase 5 (AGPAT5) in SNP DU481531_204.1 and Nuclear Receptor Subfamily 1 Group D Member 2 (NR1D2) in SNP OAR26_45130684.1 and OAR26_46516694.1. AGPAT5 converts lysophosphatidic acid (LPA) into phosphatidic acid and plays a role in LPA containing unsaturated or saturated fatty acids C15:0-C20:4 at the sn-1 position using C18:1-CoA as the acyl donor [66]. NR1D2 is found to be associated with Acinetobacter in the same region and has already been described.

\section{Clostridium}

The relative abundance of Clostridium is associated with genetic variations in region OAR2 of the sheep genome. SNP s43106.1 contained two candidate genes; RAD23 Homolog B, Nucleotide Excision Repair Protein (RAD23B) and Solute Carrier Family 44 Member 1 (SLC44A1). RAD23B is involved in cellular response to DNA damage stimulus [67] and cellular response to interleukin-7 [68]. SLC44A1 might provide choline for cell membrane phospholipid synthesis [69]. SNP OAR2_58286833_X.1 contained the TLE Family Member 1, Transcriptional Corepressor (TLE1) which inhibits NF-kappa-B-regulated gene expression in human monocytes also, increased expression of TLE1 is significant for inhibition of interleukin 12 (IL-12) p70 expression mediated by zymosan [70] also as inhibiting immune suppression induced by Bacillus anthracis toxin [71]. 


\section{Flavobacterium.}

The relative abundance of Flavobacterium was associated with genetic variations in chromosome 1, 2, 6, 16, 22 and 23 along the sheep genome. In the region of SNP OAR1_74421103.1, three candidate genes were proposed; Growth factor independence-1 (GF/1) involved in regulating the pre-T cell differentiation, hematopoietic stem cell maintenance and secretory cell types development in the intestines [72]. The formin-binding protein 1-like (FNBP1L) is critical for antibacterial autophagy [73]. The ATP Binding Cassette Subfamily D Member 3 $(A B C D 3)$ is crucial in the peroxisomal degradation of branched-chain fatty acids and biosynthesis of bile acid [74]. Unsaturated fatty acids released from bile are known to increase the solubility and absorption of saturated fatty acids in the rumen, which in turn improves fat absorption [75]. The regulation of this gene may directly influence the occurrence of Flavobacterium, as this bacteria is essential in fatty acid metabolism and biohydrogenation [76]. Three candidate genes were proposed in the region of significant SNP OAR1_197593478.1: Immunoglobulin superfamily member 11 (IGSF11), Beta-1,4-Galactosyltransferase 4 (B4GALT4), Rho GTPase Activating Protein 31 (ARHGAP31). IGSF11 functions as a cell-cell adhesion molecule in homophilic interactions and encourages cell growth [77]. B4GALT4 encodes for enzymes that play a vital role in glycosaminoglycan biosynthesis [78]. ARHGAP31 encodes a GTPase-activating protein regulating Cdc42 and Rac1 essential in protein trafficking, cell growth and cell migration [79]. SNP OAR2_247207503.1 was associated with the abundance of Flavobacterium. The SNP is located within the region of Adenylate kinase 2 (AK2) and lymphocyte Cell-Specific Protein-Tyrosine Kinase $(L C K)$, both these genes might be associated with microbial composition as their functions related with the immune system. AK2 is essential in cellular energy homeostasis and cell proliferation [80]. $L C K$ is essential in the selection and maturation of developing T-cells, and in T-cell antigen receptor (TCR)-linked signal transduction pathways [81].

Candidate genes found in the region OAR16 are associated with innate and adaptive immune responses (C9) [82]; activation of T-cell factor signaling and mediating PGE2 induced expression of early growth response 1 (PTGER4) [83]; cell growth and survival regulation responding to hormonal signals (RICTOR) [84]; activation and control of interleukin-2 expression (FYB1) [85]; cell differentiation and can induce macrophage adhesion and spreading (DAB2) [86]. Five candidate genes identified in region OAR22; NFKB2 is essential in cellular responses and in regulating the immunological responses to infections and inflammation $[87,88]$. TRIM8 plays different roles in immune pathways, such as having a positive role in the TNFalpha and IL-1beta signaling pathways [89]. CNNM2 is essential in magnesium (Mg2+) homeostasis by mediating the epithelial transport and renal reabsorption of Mg2+ [90]. FGF8 is significant in regulating the development of an embryo, cell proliferation, differentiation and migration [91]. ELOVL3 is essential in the production of monounsaturated and saturated very-long-chain fatty acids (VLCFAs) associated with numerous biological processes as precursors of lipid mediators and membrane lipids $[92,93]$. SMAD Family Member 4 (SMAD4) is the candidate gene found in the OAR23 region; it serves as a transcription activator regulating TGF-beta receptor-mediated signaling, and is involved in IL-2 activation and signaling pathway [94].

\section{Prevotella.}

Six regions on the sheep genome were associated with the abundance of Prevotella. In the region of OAR1 in the sheep genome, one candidate gene was identified; RUNX Family Transcription Factor 1 (RUNX1) which is crucial for the normal hematopoiesis development and positively regulates the expression of RAR Related Orphan Receptor C (RORC) gene in T-helper 17 cells [95]. One candidate gene was found in the region of OAR4; Glutamate metabotropic receptor 3 (GRM3) was the identified candidate gene, which is known to modulate synaptic glutamate levels that regulate stress response and a study showed fixed missense mutation on GRM3 differentiating between aggressive foxes from tame foxes [96]. In the region of OAR7, two candidate genes were identified; neural precursor cell expressed, developmentally downregulated 4 (NEDD4) and RAB27A (member RAS oncogene family). NEDD4 is a significant candidate molecular marker essential in cell proliferation, ovarian development, and sexual reproduction in zebrafish [97]. RAB27A is involved in cytotoxic granule exocytosis in lymphocytes, as it is essential for priming at the immunologic synapse and granule maturation and granule docking [98].

Three candidate genes have been found in the region OAR16: Dual Specificity Phosphatase 1 (DUSP1), BCL2 Interacting Protein 1 (BNIP1) and Stanniocalcin 2 (STC2). DUSP1 is essential in the cellular response to environmental stresses and negatively regulate cellular proliferation [99]. BNIP1 interacts with the E1B $19 \mathrm{kDa}$ protein, protecting host cells from virally induced cell death [100]. While STC2 encodes for homodimeric glycoprotein, it regulates cell metabolism, renal and intestinal calcium and phosphate transport and cellular calcium/phosphate homeostasis [101]. Prevotella microbes are involved in peptide and protein degradation in the rumen, in saccharolytic pathways and in the production of saturated fatty acids [102]. STC2 has been found to have a significant association with the relative abundance of Prevotella in cattle, and it has been previously associated to fatty acids and cell metabolism [103]; hence this gene is suggested that it could modulate the abundance of Prevotella composition in the rumen. In OAR 25 region, three candidate genes were identified, two are also found to be associated with Acinetobacter in the same region and have already been described (WDFY4 and

Page $10 / 19$ 
OGDHL). The third gene is the mitogen-activated protein kinase 4 (MAPK8) and it acts as a point of integration for multiple biochemical signals and is essential in extensive cellular processes such as transcription regulation and development, proliferation and differentiation [104].

\section{Pseudomonas.}

The relative abundance of Pseudomonas is associated with genetic variations of two regions in OAR6 and OAR14. Three candidate genes have been found in OAR6 region: 3-Hydroxybutyrate Dehydrogenase 2 (BDH2), Solute Carrier Family 9 Member B2 (SLC9B2) and CDGSH Iron Sulfur Domain 2 (CISD2). BDH2 facilitates the formation of 2,5-dihydroxybenzoic acid (2,5-DHBA), a siderophore that plays a role in iron assimilation and homeostasis, as it shares structural resemblances with bacterial enterobactin $[105,106]$. This gene may be significant in the prevention of pathogens to invade the host. SLC9B2 is essential in regulating sodium homeostasis, intracellular pH, and cell volume [107], which may be significant in regulating ruminal microbial composition. It also essential in insulin secretion and clathrinmediated endocytosis in beta-cells [108]. CISD2 regulates autophagy, contributing to antagonizing BECN1-mediated cellular autophagy at the endoplasmic reticulum [109]. Casein Kinase 2 Alpha 2 (CSNK2A2) and Glutamic-Oxaloacetic Transaminase 2 (GOT2) are two candidate genes identified in the region of OAR14. CSNK2A2 phosphorylate acidic proteins such as casein are essential in several cellular processes, like cell cycle control and circadian rhythms [110]. GOT2 is essential in amino acid metabolism and is essential for the exchange of metabolites between mitochondria and cytosol. It also enables cellular uptake of long-chain free fatty acids $[111,112]$.

\section{Streptobacillus.}

Two candidate genes found in the OAR25 region may be associated with the Streptobacillus relative abundance. Surfactant Protein A1 (SFTPA1) and Peroxiredoxin Like 2A (PRXL2A). SFTPA1 encodes a protein binding to particular carbohydrate moieties found on the surface of microorganisms and lipids. This protein is vital in the immune defence and surfactant homeostasis against respiratory pathogens [113]. PRXL2A acts as an antioxidant and negatively regulates macrophage-mediated inflammation by inhibiting the production of macrophage of inflammatory cytokines by suppressing MAPK signaling pathway [114].

\section{Conclusion}

This study identified associations between sheep genetic variations and relative abundance of seven genera; Acinetobacter, Bacillus, Clostridium, Flavobacterium, Prevotella, Pseudomonas and Streptobacillus. Candidate genes identified in the associated genetic regions encode proteins essential in host defence systems, containing the immune system, antimicrobial activities, inflammatory responses and regulation of cell adhesion and migration. In contrast, other proteins contribute to fatty acid and bile metabolism and other biochemical processes. The results confirm that host genetics is important in modulating microbial composition; nonetheless, the association found in this study may be population-specific as various factors alter the rumen microbiota. More studies are necessary for diverse populations to help determine genetic combinations favourable for the enhancement of beneficial microbiota and provide excellent intestinal health to the individuals and avoid the invasion of potential pathogens.

\section{Abbreviations}

FDR: False discovery rate, GWAS: Genome-wide association studies, MAF: Minor allele frequency, OTU: Operational taxonomic units, SNP: Single nucleotide polymorphism.

\section{Declarations}

\section{Acknowledgements}

Authors will like to acknowledge the Agricultural Research Council - Animal Production, Irene, South Africa; National Research Foundation (NRF) of South Africa and University of Kwa-Zulu Natal, Discipline of Genetics for funds and provision of research facilities.

\section{Authors' contribution}


SM, OAA and MAA designed the experiment, SM carried all the laboratory work and analyses. SM drafted the manuscript. OAA and MAA revised the manuscript. All authors read and approved the final manuscript.

\section{Funding}

Authors will like to acknowledge the Agricultural Research Council - Animal Production, Irene, South Africa; National Research Foundation (NRF) of South Africa and University of Kwa-Zulu Natal, Discipline of Genetics for funds and provision of research facilities,

\section{Availability of data and materials}

Raw reads used in the present study were deposited to the National Center of Biotechnology Information (NCBI) Sequence Read Archive (SRA) database under BioProject PRJNA578022 (https://www.ncbi.nlm.nih.gov/bioproject/?term=PRJNA578022). The datasets used and/or analysed during the current study are available from the corresponding author on reasonable request.

\section{Ethics approval and consent to participate}

All the procedures involving animals were in accordance with guidelines of the Agricultural Research Council - Animal Production Ethics committee (APIEC17/21).

\section{Consent for publication}

Not applicable.

\section{Competing interests}

The authors declare that they have no competing interests.

\section{Authors' information}

${ }^{a}$ Agricultural Research Council- Animal Production Institute, GI Microbiology and Biotechnology Unit, Irene, South Africa. ${ }^{b}$ Discipline of Genetics, School of Life Sciences, College of Agriculture, Engineering and Science, University of KwaZulu-Natal, Westville, P/Bag X54001, Durban 4000, South Africa. ' Unit for Environmental Sciences and Management, North West University, Potchefstroom 2520 , South Africa.

\section{References}

1. Zhao L, Wang G, Siegel P, He C, Wang H, Zhao W, et al. Quantitative genetic background of the host influences gut microbiomes in chickens. Sci Rep. 2013;3:1-6.

2. Guo W, Li Y, Wang L, Wang J, Xu Q, Yan T, et al. Evaluation of composition and individual variability of rumen microbiota in yaks by 16S rRNA high-throughput sequencing technology. 34. Anaerobe: Elsevier Ltd; 2015. pp. 74-9.

3. Goodrich JK, Davenport ER, Waters JL, Clark AG, Ley RE. Cross-species comparisons of host genetic associations with the microbiome. Science. 2016;352(6285):523-35.

4. Malmuthuge N, Griebel PJ, Guan LL. The Gut Microbiome and Its Potential Role in the Development and Function of Newborn Calf Gastrointestinal Tract. Front Vet Sci. 2015;2(September):1-10.

5. Henderson G, Cox F, Ganesh S, Jonker A, Young W, Abecia L, et al. Rumen microbial community composition varies with diet and host, but a core microbiome is found across a wide geographical range. Sci Rep. 2015;5(1):14567.

6. Ellison MJ, Conant GC, Lamberson WR, Cockrum RR, Austin KJ, Rule DC, et al. Diet and feed efficiency status affect rumen microbial profiles of sheep. Small Rumin Res. 2017;156(February):12-9.

7. Li F, Li C, Chen Y, Liu J, Zhang C, Irving B, et al. Host genetics influence the rumen microbiota and heritable rumen microbial features associate with feed efficiency in cattle. Microbiome Microbiome. 2019;7(1):1-17. 
8. Blekhman R, Goodrich JK, Huang K, Sun Q, Bukowski R, Bell JT, et al. Host genetic variation impacts microbiome composition across human body sites. Genome Biol Genome Biology. 2015;16(1):191.

9. Oliveira PSN de, Cesar ASM, Nascimento ML do, Chaves AS, Tizioto PC, Tullio RR, et al. Identification of genomic regions associated with feed efficiency in Nelore cattle. BMC Genet. 2014; 15:100.

10. Benavides MV, Sonstegard TS, Kemp S, Mugambi JM, Gibson JP, Baker RL, et al. Identification of novel loci associated with gastrointestinal parasite resistance in a red Maasai x Dorper backcross population. PLoS One. 2015;10(4):1-20.

11. Zvinorova PI. A genome-wide association study on mechanisms underlying genetic resistance to gastrointestinal parasites in goats. 2017; (March).

12. Sasson G, Ben-Shabat SK, Seroussi E, Doron-Faigenboim A, Shterzer N, Yaacoby S, et al. Heritable bovine rumen bacteria are phylogenetically related and correlated with the cow's capacity to harvest energy from its feed. MBio. 2017;8(4):1-12.

13. Crespo-Piazuelo D, Migura-Garcia L, Estellé J, Criado-Mesas L, Revilla M, Castelló A, et al. Association between the pig genome and its gut microbiota composition. Sci Rep. 2019;9(1):1-11.

14. Shen JS, Chai Z, Song LJ, Liu JX, Wu YM. Insertion depth of oral stomach tubes may affect the fermentation parameters of ruminal fluid collected in dairy cows1. J Dairy Sci. 2012;95(10):5978-84.

15. Bolyen E, Dillon M, Bokulich N, Abnet C, Al-Ghalith G, Alexander H, et al. QIIME 2: Reproducible, interactive, scalable, and extensible microbiome data science. PeerJ Prepr. 2018.

16. Purcell S, Neale B, Todd-Brown K, Thomas L, Ferreira MAR, Bender D, et al. PLINK: A tool set for whole-genome association and population-based linkage analyses. Am J Hum Genet. 2007;81(3):559-75.

17. Benjamini-hochberg. Controlling the False Discovery Rate: A Practical and Powerful Approach to Multiple Testing. JR Stat B. 1995;57(1):289-300.

18. Kinsella RJ, Kähäri A, Haider S, Zamora J, Proctor G, Spudich G, et al. Ensembl BioMarts: A hub for data retrieval across taxonomic space. Database. 2011;2011:1-9.

19. McLaren W, Pritchard B, Rios D, Chen Y, Flicek P, Cunningham F. Deriving the consequences of genomic variants with the Ensembl API and SNP Effect Predictor. Bioinformatics. 2010;26(16):2069-70.

20. Lanning NJ, Looyenga BD, Kauffman AL, Niemi NM, Sudderth J, DeBerardinis RJ, et al. A Mitochondrial RNAi Screen Defines Cellular Bioenergetic Determinants and Identifies an Adenylate Kinase as a Key Regulator of ATP Levels. Cell Rep. 2014;7(3):907-17.

21. Jan YH, Lai TC, Yang CJ, Lin YF, Huang MS, Hsiao M. Adenylate kinase 4 modulates oxidative stress and stabilizes HIF-1 a to drive lung adenocarcinoma metastasis. J Hematol Oncol Journal of Hematology Oncology. 2019;12(1):1-14.

22. Clément K, Vaisse C, Lahlou N, Cabrol S, Pelloux V, Cassuto D, et al. A mutation in the human leptin receptor gene causes obesity and pituitary dysfunction. Nature. 1998;392(6674):398-401.

23. Fournier HN, Dupé-Manet S, Bouvard D, Lacombe ML, Marie C, Block MR, et al. Integrin cytoplasmic domain-associated protein 1a (ICAP-1a) interacts directly with the metastasis suppressor nm23-H2, and both proteins are targeted to newly formed cell adhesion sites upon integrin engagement. J Biol Chem. 2002;277(23):20895-902.

24. Takeda Y, Matoba K, Kawanami D, Nagai Y, Akamine T, Ishizawa S, et al. ROCK2 regulates monocyte migration and cell to cell adhesion in vascular endothelial cells. Int J Mol Sci. 2019; 20(6).

25. Xiang R, McNally J, Bond J, Tucker D, Cameron M, Donaldson AJ, et al. Across-experiment transcriptomics of sheep rumen identifies expression of lipid/oxo-acid metabolism and muscle cell junction genes associated with variation in methane-related phenotypes. Front Genet. 2018;9:330.

26. Liu LC, Wang YL, Lin P, Le, Zhang X, Cheng WC, Liu SH, et al. Long noncoding RNA HOTAIR promotes invasion of breast cancer cells through chondroitin sulfotransferase CHST15. Int J Cancer. 2019;145(9):2478-87.

27. Zheng H, Gupta V, Patterson-fortin J, Bhattacharya S, Katlinski K, Wu J, et al. A Novel BRISC-SHMT Complex Deubiquitinates IFNAR1 and Regulates Interferon Responses Hui. Cell Rep. 2014;5(1):1-28.

28. Bai SW, Herrera-Abreu MT, Rohn JL, Racine V, Tajadura V, Suryavanshi N, et al. Identification and characterization of a set of conserved and new regulators of cytoskeletal organization, cell morphology and migration. BMC Biol. $2011 ; 9$.

29. Theisen DJ, Davidson JT, Briseño CG, Gargaro M, Lauron EJ, Wang Q, et al. WDFY4 is required for cross-presentation in response to viral and tumor antigens. Science. 2018;362(6415):694-9.

30. Dai W, Xu L, Yu X, Zhang G, Guo H, Liu H, et al. OGDHL silencing promotes hepatocellular carcinoma by reprogramming glutamine metabolism. Journal of Hepatology. 2020.

Page 13/19 
31. Stepp MW, Folz RJ, Yu J, Zelko IN. The c10orf10 gene product is a new link between oxidative stress and autophagy. Biochim Biophys Acta - Mol Cell Res. 2014;1843(6):1076-88.

32. Ramakrishnan SN, Muscat GEO. The Orphan Rev-Erb Nuclear Receptors: A Link between Metabolism, Circadian Rhythm and Inflammation? Nucl Recept Signal. 2006;4(1):nrs.04009.

33. Mao S, Zhang M, Liu J, Zhu W. Characterising the bacterial microbiota across the gastrointestinal tracts of dairy cattle: Membership and potential function. Sci Rep Nature Publishing Group. 2015;5(October):1-14.

34. Ilinskaya ON, Ulyanova VV, Yarullina DR, Gataullin IG. Secretome of Intestinal bacilli: A natural guard against pathologies. Front Microbiol. 2017;8(SEP):1-15.

35. Han HJ, Tokino T, Nakamura Y. CSR, a scavenger receptor-like protein with a protective role against cellular damage caused by UV irradiation and oxidative stress. Hum Mol Genet. 1998;7(6):1039-46.

36. Rivera Rosado LA, Horn TA, McGrath SC, Cotter RJ, Yang JT. Association between a4 integrin cytoplasmic tail and non-muscle myosin IIA regulates cell migration. J Cell Sci. 2011;124(3):483-92.

37. Manning AK, Hivert MF, Scott RA, Grimsby JL, Bouatia-Naji N, Chen H, et al. A genome-wide approach accounting for body mass index identifies genetic variants influencing fasting glycemic traits and insulin resistance. Nat Genet. 2012;44(6):659-69.

38. Wu Q, Guo D, Bi H, Wang D, Du Y. UVB irradiation-induced dysregulation of plasma membrane calcium ATPase1 and intracellular calcium homeostasis in human lens epithelial cells. Mol Cell Biochem. 2013;382(1-2):263-72.

39. Lehto M, Mäyränpää MI, Pellinen T, Ihalmo P, Lehtonen S, Kovanen PT, et al. The R-Ras interaction partner ORP3 regulates cell adhesion. J Cell Sci. 2008;121(5):695-705.

40. Vázquez MJ, González CR, Varela L, Lage R, Tovar S, Sangiao-Alvarellos S, et al. Central resistin regulates hypothalamic and peripheral lipid metabolism in a nutritional-dependent fashion. Endocrinology. 2008;149(9):4534-43.

41. Liu H, Shim AHR, He X. Structural characterization of the ectodomain of a disintegrin and metalloproteinase-22 (ADAM22), a neural adhesion receptor instead of metalloproteinase. Insights on adam function. J Biol Chem. 2009;284(42):29077-85.

42. Zimmermann S, Pfannkuch L, Al-Zeer MA, Bartfeld S, Koch M, Liu J, et al. ALPK1- and TIFA-Dependent Innate Immune Response Triggered by the Helicobacter pylori Type IV Secretion System. Cell Rep. 2017;20(10):2384-95.

43. Milivojevic M, Dangeard AS, Kasper CA, Tschon T, Emmenlauer M, Pique C, et al. ALPK1 controls TIFA/TRAF6-dependent innate immunity against heptose-1,7-bisphosphate of gram-negative bacteria. PLoS Pathog. 2017;13(2):1-28.

44. Arnaud C, Sebbagh M, Nola S, Audebert S, Bidaut G, Hermant A, et al. MCC, a new interacting protein for Scrib, is required for cell migration in epithelial cells. FEBS Lett Federation of European Biochemical Societies. 2009;583(14):2326-32.

45. Ishiguro H, Furukawa Y, Daigo Y, Miyoshi Y, Nagasawa Y, Nishiwaki T, et al. Isolation and characterization of human NBL4, a gene involved in the $\beta$-catenin/Tcf signaling pathway. Japanese J Cancer Res. 2000;91(6):597-603.

46. Michelucci A, Cordes T, Ghelfi J, Pailot A, Reiling N, Goldmann O, et al. Immune-responsive gene 1 protein links metabolism to immunity by catalyzing itaconic acid production. Proc Natl Acad Sci U S A. 2013;110(19):7820-5.

47. Fu W, Cheng Y, Zhang Y, Mo X, Li T, Liu Y, et al. The Secreted Form of Transmembrane Protein 98 Promotes the Differentiation of T Helper 1 Cells. J Interf Cytokine Res. 2015;35(9):720-33.

48. Abbott KL, Troupe K, Lee I, Pierce M. Integrin-dependent neuroblastoma cell adhesion and migration on laminin is regulated by expression levels of two enzymes in the 0-mannosyl-linked glycosylation pathway, PomGnT1 and GnT-Vb. Exp Cell Res. 2006;312(15):2837-50.

49. Samyn-Petit B, Krzewinski-Recchi MA, Steelant WFA, Delannoy P, Harduin-Lepers A. Molecular cloning and functional expression of human ST6GaINAc II. Molecular expression in various human cultured cells. Biochim Biophys Acta - Gen Subj. 2000;1474(2):201-11.

50. Hodges NJ, Innocent N, Dhanda S, Graham M. Cellular protection from oxidative DNA damage by over-expression of the novel globin cytoglobin in vitro. Mutagenesis. 2008;23(4):293-8.

51. Kee TH, Vit P, Malendez AJ. BRIEF REVIEW SPHINGOSINE KINASE SIGNALLING. IN IMMUNE CELLS Tay Hwee Kee, Patricia Vit and Alirio J Melendez. Clin Exp Pharmacol Physiol. 2005;32:153-61.

52. Baltazar ET, Kitamura N, Sasaki M, Cottrell DF, Boloron HMR, Yamada J. Galanin-like Immunoreactive Neural Elements in Domestic Ruminant Pancreas. J Vet Med Sci. 2001;63(8):841-8.

53. Petry K, Reichardt J. The fundamental importance of human galactose metabolism: Lessons from genetics and biochemistry. Trends Genet. 1998;14(3):98-102. 54. 
54. Murakami Y, Kohyama N, Kobayashi Y, Ohbayashi M, Ohtani H, Sawada Y, et al. FUNCTIONAL CHARACTERIZATION OF HUMAN MONOCARBOXYLATE TRANSPORTER 6 (SLC16A5) Yuichi Murakami. Pharmacology. 2005;33(12):1845-51. Noriko Kohyama, Yasuna Kobayashi, Masayuki Ohbayashi, Hisakazu Ohtani, ABSTRACT.

55. Tu YH, Cooper AJ, Teng B, Chang RB, Artiga DJ, Turner HN, et al. An evolutionarily conserved gene family encodes proton-selective ion channels. Science. 2018;359(6379):1047-50.

56. Niknami M, Patel M, Witting PK, Dong Q. Molecules in focus: Cytosolic phospholipase A2-a. Int J Biochem Cell Biol. 2009;41(5):9947.

57. Pourcelot M, Zemirli N, Silva Da Costa L, Loyant R, Garcin D, Vitour D, et al. The Golgi apparatus acts as a platform for TBK1 activation after viral RNA sensing. BMC Biol BMC Biology. 2016;14(1):1-17.

58. Funaro A, Spagnoli GC, Momo M, Knapp W, Malavasi F. Stimulation of T cells via CD44 requires leukocyte-function-associated antigen interactions and interleukin-2 production. Hum Immunol. 1994;40(4):267-78.

59. Yoshida T, Matsuda Y, Naito Z, Ishiwata T. CD44 in human glioma correlates with histopathological grade and cell migration. Pathol Int. 2012;62(7):463-70.

60. Zhang X, Ibrahimi OA, Olsen SK, Umemori H, Mohammadi M, Ornitz DM. Receptor specificity of the fibroblast growth factor family: The complete mammalian FGF family. J Biol Chem. 2006;281(23):15694-700.

61. Wei MH, Karavanova I, Ivanov SV, Popescu NC, Keck CL, Pack S, et al. In silico-initiated cloning and molecular characterization of a novel human member of the L1 gene family of neural cell adhesion molecules. Hum Genet. 1998;103(3):355-64.

62. Murray P, Frampton G, Nelson PN. Cell adhesion molecules. Sticky moments in the clinic. BMJ. 1999;319(7206):332-4.

63. Forny P, Froese DS, Suormala T, Yue WW, Baumgartner MR. Functional characterization and categorization of missense mutations that cause methylmalonyl-coA mutase (MUT) deficiency. Hum Mutat. 2014;35(12):1449-58.

64. Jeffries KA, Dempsey DR, Farrell EK, Anderson RL, Garbade GJ, Gurina TS, et al. Glycine N-acyltransferase-like 3 is responsible for long-chain N-acylglycine formation in N18TG2 cells. J Lipid Res. 2016;57(5):781-90.

65. Valdearcos M, Esquinas E, Meana C, Peña L, Gil-de-Gómez L, Balsinde J, et al. Lipin-2 reduces proinflammatory signaling induced by saturated fatty acids in macrophages. J Biol Chem. 2012;287(14):10894-904.

66. Prasad SS, Garg A, Agarwal AK. Enzymatic activities of the human AGPAT isoform 3 and isoform 5: Localization of AGPAT5 to mitochondria. J Lipid Res. 2011;52(3):451-62.

67. Ng JMY, Vermeulen W, Horst GTJ, Van der, Bergink S, Sugasawa K, Vrieling H, et al. A novel regulation mechanism of DNA repair by damage-induced and RAD23-dependent stabilization of xeroderma pigmentosum group C protein. Genes Dev. 2003;17(13):1630-45.

68. Aiello FB, Guszczynski T, Li W, Hixon JA, Jiang Q, Hodge DL, et al IL-7-induced phosphorylation of the adaptor Crk-like and other targets. Cell Signal. Elsevier Inc; 2018; 47:131-41. 69. Traiffort E, O’Regan S, Ruat M. The choline transporter-like family SLC44: Properties and roles in human diseases. Mol Aspects Med. 2013; 34(2-3):646-54.

69. Alvarez Y, Municio C, Hugo E, Zhu J, Alonso S, Hu X, et al. Notch- and transducin-like enhancer of split (TLE)-dependent histone deacetylation explain interleukin 12 (IL-12) p70 inhibition by zymosan. J Biol Chem. 2011;286(19):16583-95.

70. Larabee JL, Shakir SM, Barua S, Ballard JD. Increased cAMP in monocytes augments notch signaling mechanisms by elevating RBP$J$ and transducin-like enhancer of split (TLE). J Biol Chem. 2013;288(30):21526-36.

71. Qu X, Nyeng P, Xiao F, Dorantes J, Jensen J. Growth Factor Independence-1 (Gfi1) Is Required for Pancreatic Acinar Unit Formation and Centroacinar Cell Differentiation. Cell Mol Gastroenterol Hepatol Elsevier. 2015;1(2):233-47.

72. Park S, Choi Y, Namhee J, Kim J, Oh S, Yu Y, et al. Autophagy induction in the skeletal myogenic differentiation of human tonsilderived mesenchymal stem cells. Int J Mol Med. 2017;39(4):831-40.

73. Baker A, Carrier DJ, Schaedler T, Waterham HR, Roermund CW, Van, Theodoulou FL. Peroxisomal ABC transporters: Functions and mechanism. Biochem Soc Trans. 2015;43:959-65.

74. Leat W, Harrison F. LIPID DIGESTION IN, THE SHEEP: EFFECT OF BILE AND PANCREATIC JUICE ON THE LIPIDS OF INTESTINAL CONTENTS. Q JI exp Physiol. 1969;54:187-201.

75. McKain N, Shingfield KJ, Wallace RJ. Metabolism of conjugated linoleic acids and 18: 1 fatty acids by ruminal bacteria: Products and mechanisms. Microbiology. 2010;156(2):579-88.

76. Harada H, Suzu S, Hayashi Y, Okada S. BT-IgSF, a novel immunoglobulin superfamily protein, functions as a cell adhesion molecule. J Cell Physiol. 2005;204(3):919-26. 
77. Gao Y, Wang X, Yan H, Zeng J, Ma S, Niu Y, et al. Comparative transcriptome analysis of fetal skin reveals key genes related to hair follicle morphogenesis in cashmere goats. PLoS One. 2016;11(3):1-20.

78. Materna-Kiryluk A, Kiryluk K, Burgess KE, Bieleninik A, Sanna-Cherchi S, Gharavi AG, et al. The emerging role of genomics in the diagnosis and workup of congenital urinary tract defects: A novel deletion syndrome on chromosome 3q13.31-22.1. Pediatr Nephrol. 2014;29(2):257-67.

79. Chen RP, Liu CY, Shao HL, Zheng WW, Wang JX, Zhao XF. Adenylate kinase 2 (AK2) promotes cell proliferation in insect development. BMC Mol Biol. 2012; 13(1).

80. Jung SH, Yoo EH, Yu MJ, Song HM, Kang HY, Cho J-Y, et al. ARAP, a Novel Adaptor Protein, Is Required for TCR Signaling and IntegrinMediated Adhesion. J Immunol. 2016;197(3):942-52.

81. Spicer BA, Law RHP, Caradoc-Davies TT, Ekkel SM, Bayly-Jones C, Pang SS, et al. The first transmembrane region of complement component-9 acts as a brake on its self-assembly. Nat Commun. 2018; 9(1).

82. Okano M, Sugata Y, Fujiwara T, Matsumoto R, Nishibori M, Shimizu K, et al. E prostanoid 2 (EP2)/EP4-mediated suppression of antigen-specific human T-cell responses by prostaglandin E2. Immunology. 2006;118(3):343-52.

83. Sarbassov D, Ali. Rictor, a Novel Binding Partner of mTOR, Defines a Rapamycin-Insensitive and Raptor-Independent Pathway that Regulates the Cytoskeleton. Icarus. 2014;231:65.

84. Veale M, Raab M, Li Z, Silva AJ, Da, Kraeft SK, Weremowicz S, et al. Novel isoform of lymphoid adaptor FYN-T-binding protein (FYB130) interacts with SLP-76 and up-regulates interleukin 2 production. J Biol Chem. 1999;274(40):28427-35.

85. Rosenbauer F. Disabled-2 is transcriptionally regulated by ICSBP and augments macrophage spreading and adhesion. EMBO J. 2002;21(3):211-20.

86. Manna SK, Aggarwal BB. Differential Requirement for p56 Ick in HIV-tat Versus TNF-Induced Cellular Responses: Effects on NF-KB, Activator Protein-1, c-Jun N-Terminal Kinase, and Apoptosis. J Immunol. 2000;164(10):5156-66.

87. Krljanac B, Weih D, Jacobsen ID, Hu D, Koliesnik I, Reppe K, et al. NF-KB2/p100 deficiency impairs immune responses to T-cellindependent type 2 antigens. Eur J Immunol. 2014;44(3):662-72.

88. Li Q, Yan J, Mao AP, Li C, Ran Y, Shu HB, et al. Tripartite motif 8 (TRIM8) modulates TNFa- and IL-1 $\beta$-triggered NF-kB activation by targeting TAK1 for K63-linked polyubiquitination. Proc Natl Acad Sci U S A. 2011;108(48):19341-6.

89. Corral-Rodríguez M, Stuiver M, Abascal-Palacios G, Diercks T, Oyenarte I, Ereño-Orbea J, et al. Nucleotide binding triggers a conformational change of the CBS module of the magnesium transporter CNNM2 from a twisted towards a flat structure. Biochem J. 2014;464:23-34.

90. Pei Y, Sun X, Guo X, Yin H, Wang L, Tian F, et al. FGF8 promotes cell proliferation and resistance to EGFR inhibitors via upregulation of EGFR in human hepatocellular carcinoma cells. Oncol Rep. 2017;38(4):2205-10.

91. Leonard AE, Bobik EG, Dorado J, Kroeger PE, Chuang LT, Thurmond JM, et al. Cloning of a human cDNA encoding a novel enzyme involved in the elongation of long-chain polyunsaturated fatty acids. Biochem J. 2000;350(3):765-70.

92. Westerberg R, Månsson JE, Golozoubova V, Shabalina IG, Backlund EC, Tvrdik P, et al. ELOVL3 is an important component for early onset of lipid recruitment in brown adipose tissue. J Biol Chem. 2006;281(8):4958-68.

93. Yang Y, Zhou QJ, Chen XQ, Yan BL, Guo XL, Zhang HL, et al. Profiling of differentially expressed genes in sheep T lymphocytes response to an artificial primary Haemonchus contortus infection. Parasites Vectors ??? 2015;8(1):1-12. Available from: ???.

94. Fujimoto T, Anderson K, Jacobsen SEW, Nishikawa SI, Nerlov C. Cdk6 blocks myeloid differentiation by interfering with Runx1 DNA binding and Runx1-C/EBPa interaction. EMBO J. 2007;26(9):2361-70.

95. Wang X, Pipes L, Trut LN, Herbeck Y, Vladimirova AV, Gulevich RG, et al. Genomic responses to selection for tame/aggressive behaviors in the silver fox (Vulpes vulpes). Proc Natl Acad Sci U S A. 2018;115(41):10398-403.

96. Wiszniak S, Harvey N, Schwarz Q. Cell autonomous roles of Nedd4 in craniofacial bone formation. Dev Biol Elsevier. 2016;410(1):98107.

97. Herrero-Turrión MJ, Calafat J, Janssen H, Fukuda M, Mollinedo F. Rab27a Regulates Exocytosis of Tertiary and Specific Granules in Human Neutrophils. J Immunol. 2008;181(6):3793-803.

98. Shen J, Zhou S, Shi L, Liu X, Lin H, Yu H, et al. DUSP1 inhibits cell proliferation, metastasis and invasion and angiogenesis in gallbladder cancer. Oncotarget. 2017;8(7):12133-44.

99. Boyd JM, Malstrom S, Subramanian T, Venkatesh LK, Schaeper U, Elangovan B, et al. Adenovirus E1B 19 kDa and Bcl-2 proteins interact with a common set of cellular proteins. Cell. 1994;79(2):341-51. 
100. Meyer HA, Tölle A, Jung M, Fritzsche FR, Haendler B, Kristiansen I, et al. Identification of Stanniocalcin 2 as Prognostic Marker in Renal Cell Carcinoma. Eur Urol. 2009;55(3):669-78.

101. Stevenson DM, Weimer PJ. Dominance of Prevotella and low abundance of classical ruminal bacterial species in the bovine rumen revealed by relative quantification real-time PCR. Appl Microbiol Biotechnol. 2007;75(1):165-74.

102. Gonzalez-Recio O, Zubiria I, García-Rodríguez A, Hurtado A, Atxaerandio R. Short communication: Signs of host genetic regulation in the microbiome composition in 2 dairy breeds: Holstein and Brown Swiss. J Dairy Sci. 2018;101(3):2285-92.

103. Wang Q, Zhou Y, Wang X, Chung DH, Evers BM. Regulation of Pten Expression in Intestinal Epithelial Cells By Jnk Activation and NfKb Inhibition. Cancer Res. 2007;67(16):7773-81.

104. Devireddy L, Hart D, Goetz D, Green M. A Mammalian Siderophore Synthesized by an Enzyme with a Bacterial Homologue Involved in Enterobactin Production Laxminarayana. Cell. 2010;141(6):1006-17.

105. Liu Z, Reba S, Chen WD, Porwal SK, Boom WH, Petersen RB, et al. Regulation of mammalian siderophore 2,5-DHBA in the innate immune response to infection. J Exp Med. 2014;211(6):1197-213.

106. Yan L, Shen Z, Lu Z. Increases in the expression of $\mathrm{Na}+/ \mathrm{H}+$ exchanger 1 and 3 are associated with insulin signalling in the ruminal epithelium. J Anim Physiol Anim Nutr (Berl). 2018;102(2):e569-77.

107. Deisl C, Simonin A, Anderegg M, Albano G, Kovacs G, Ackermann D, et al. Sodium/hydrogen exchanger NHA2 is critical for insulin secretion in $\beta$-cells. Proc Natl Acad Sci U S A. 2013;110(24):10004-9.

108. Chang NC, Nguyen M, Germain M, Shore GC. Antagonism of Beclin 1-dependent autophagy by BCL-2 at the endoplasmic reticulum requires NAF-1. EMBO J. Nature Publishing Group; 2010; 29(3):606-18. Available from: http://dx.doi.org/10.1038/emboj.2009.369.

109. Yang Y, Cheng P, Liu Y. Regulation of the Neurospora circadian clock by casein kinase II. Genes Dev. 2002;16(8):994-1006.

110. Blüher S, Käpplinger J, Herget S, Reichardt S, Böttcher Y, Grimm A, et al. Cardiometabolic risk markers, adipocyte fatty acid binding protein (aFABP) and the impact of high-intensity interval training (HIIT) in obese adolescents. Metabolism. Elsevier Inc.; 2017; 68:7787.

111. Hong R, Zhang W, Xia X, Zhang K, Wang Y, Wu M, et al. Preventing BRCA1/ZBRK1 repressor complex binding to the GOT2 promoter results in accelerated aspartate biosynthesis and promotion of cell proliferation. Mol Oncol. 2019;13(4):959-77.

112. Pinnell N, Yan R, Cho HJ, Keeley T, Murai MJ, Liu Y, et al. The PIAS-like coactivator Zmiz1 is a direct and selective cofactor of Notch1 in T-cell development and leukemia. Immunity. 2015;43(5):870-83.

113. Fang G, Hui H, Fu ZC, Huang S, Chen T, Papasian CJ, et al. Adipocyte-derived PAMM suppresses macrophage inflammation by inhibiting MAPK signalling. Biochem J. 2015;472(3):309-18.

\section{Figures}



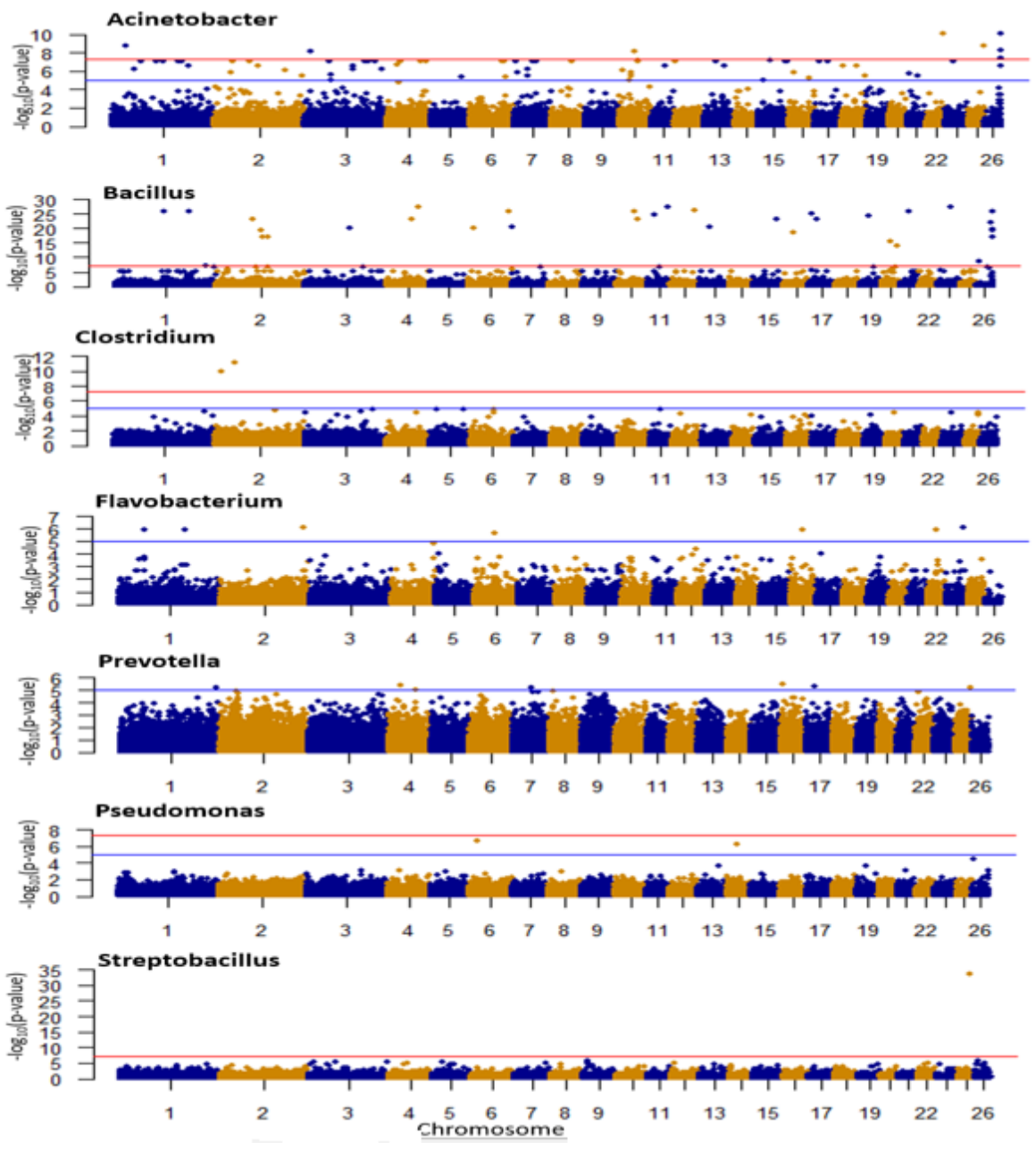

\section{Figure 1}

Manhattan plot showing -log scale p-values (y-axis) of SNPs associated with the relative abundance of the following genera (Acinetobacter, Bacillus, Clostridium, Flavobacterium, Prevotella, Pseudomonas and Streptobacillus) on the ovine chromosomal positions (x-axis). Red lines indicate SNPs above the genome-wide significance threshold (FDR $\leq 0.05$ ) and blue lines show SNPs below the genome-wide significance threshold (FDR $\leq 0.1$ 

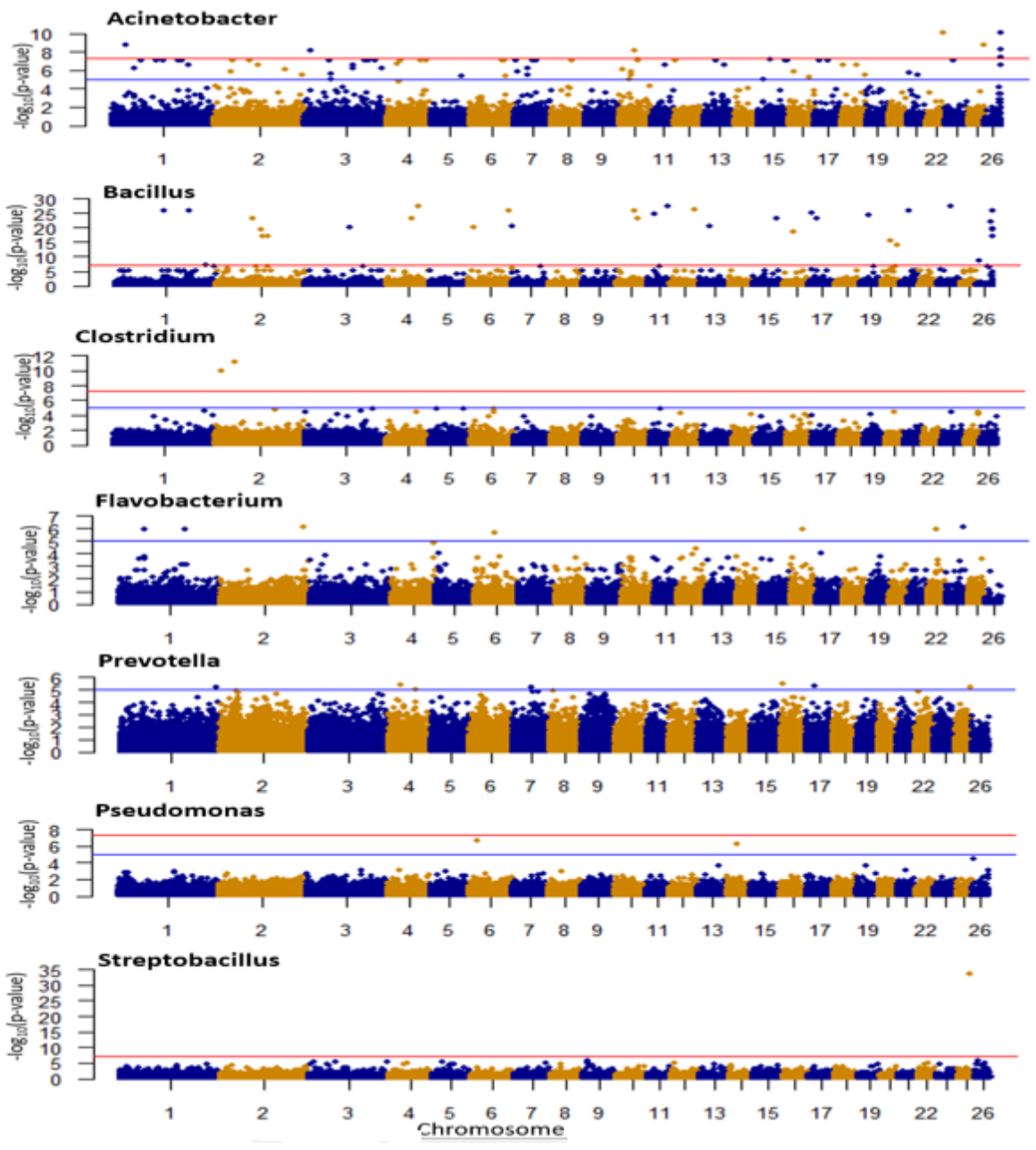

\section{Figure 1}

Manhattan plot showing -log scale p-values (y-axis) of SNPs associated with the relative abundance of the following genera (Acinetobacter, Bacillus, Clostridium, Flavobacterium, Prevotella, Pseudomonas and Streptobacillus) on the ovine chromosomal positions (x-axis). Red lines indicate SNPs above the genome-wide significance threshold (FDR $\leq 0.05$ ) and blue lines show SNPs below the genome-wide significance threshold (FDR $\leq 0.1$ 